\title{
PNPLA3-A Potential Therapeutic Target for Personalized Treatment of Chronic Liver Disease
}

Xiaocheng Charlie Dong*

Center for Diabetes and Metabolic Diseases, Department of Biochemistry and Molecular Biology, Indiana University School of Medicine, Indianapolis, IN, United States

Patatin-like phospholipase domain-containing protein 3 (PNPLA3) is a lipid droplet-associated protein that has been shown to have hydrolase activity toward triglycerides and retinyl esters. The first evidence of PNPLA3 being associated with fatty liver disease was revealed by a genome-wide association study (GWAS) of Hispanic, African American, and European American individuals in the Dallas Heart Study back in 2008. Since then, numerous GWAS reports have shown that PNPLA3 rs738409[G] (148M) variant is associated with hepatic triglyceride accumulation (steatosis), inflammation, fibrosis, cirrhosis, and even hepatocellular carcinoma regardless of etiologies including alcohol- or obesity-related and others. The frequency of PNPLA3(148M) variant ranges from 17\% in African Americans, 23\% in European Americans, to $49 \%$ in Hispanics in the Dallas Heart Study. Due to high prevalence of obesity and alcohol consumption in modern societies, the PNPLA3(148M) gene variant and environment interaction poses a serious concern for public health, especially chronic liver diseases including alcohol-related liver disease (ALD) and nonalcoholic fatty liver disease (NAFLD). Therefore, PNPLA3(148M) variant is a potential therapeutic target for chronic liver disease in the rs738409 allele carriers. Currently, there is no approved drug specifically targeting the PNPLA3(148M) variant yet. With additional mechanistic studies, novel therapeutic strategies are expected to be developed for the treatment of the PNPLA3(148M) variant-associated chronic liver diseases in the near future.

Keywords: PNPLA3, rs738409, nonalcoholic steatohepatitis, alcoholic liver disease, fibrosis, cirrhosis, hepatocellular carcinoma

Alcoholic and non-alcoholic fatty liver diseases (ALD and NAFLD) have become serious public health burdens in the modern societies (1). ALD and NAFLD are chronic liver disorders that begin with hepatic triglyceride accumulation (steatosis) and progress to hepatic inflammation and fibrosis, cirrhosis and even liver cancer $(2,3)$. The causes of these liver diseases are multifactorial, including genetic, and environmental factors. Excess alcohol consumption, over nutrition, and physical inactivity are significant environmental risk factors $(4,5)$. It is believed that hepatic steatosis sets a stage for elevated susceptibility to acute and chronic inflammation in the liver. Multiple cytokines and chemokines including transforming growth factor- $\beta$ (TGF- $\beta$ ) secreted from inflammatory immune cells trigger an activation of hepatic stellate cells (HSCs) and subsequently hepatic fibrogenesis (6).

In addition to those environmental factors, numerous genetic variants have been shown to be associated with ALD and NAFLD, including patatin-like phospholipase domain-containing protein 3 (PNPLA3), transmembrane 6 superfamily member 2 (TM6SF2), glucokinase regulator (GCKR), 
membrane bound O-acyltransferase domain-containing 7 (MBOAT7), and hydroxysteriod 17-beta dehydrogenase 13 (HSD17B13) $(7,8)$. TM6SF2 is involved in the VLDL secretion (9-15). The rs58542926 C>T variant of TM6SF2 decreases the VLDL secretion and increases hepatic triglycerides (1625). GCKR regulates the glucokinase activity in the liver (26). The rs780094 $\mathrm{A}>\mathrm{G}$ and rs1260326 $\mathrm{C}>\mathrm{T}$ variants of GCKR lead to the loss of control of hepatic glucose influx and therefore increase hepatic lipogenesis (27-38). MBOAT7 catalyzes the acyl chain remodeling of phosphatidylinositol and decreases free arachidonic acid levels (39, 40). The rs641738 C $>\mathrm{T}$ variant of MBOAT7 increases arachidonic acid levels and hepatic inflammation (41-54). HSD17B13 has been shown to have retinol dehydrogenase activity (55). The rs72613567:TA variant of HSD17B13 is associated with increased steatosis and decreased inflammation and fibrosis (56-64). PNPLA3 has drawn a remarkable attention in the liver field since the first genome-wide association study (GWAS) revealed that a single nucleotide polymorphism (SNP) in the human PNPLA3 gene-rs738409[G] (148M) is the only non-synonymous sequence variant significantly associated with hepatic fat content in the Dallas Heart Study cohort (65).
Multiple genetic studies have since validated the association of PNPLA3(148M) with a broad spectrum of liver diseases ranging from ALD and NAFLD, non-alcoholic steatohepatitis (NASH), fibrosis, cirrhosis, and hepatocellular carcinoma (HCC) $(33,66-117)$. However, the underlying pathogenic mechanisms remain elusive. This review aims to briefly summarize the PNPLA3 biology, clinical implications, and therapeutic development strategies.

\section{PNPLA3 GENE FUNCTION}

PNPLA3 has multiple names in the literature including adiponutrin (ADPN), calcium-independent phospholipase A2epsilon (IPLA2epsilon, and chromosome 22 open reading frame 20 (C22orf20). In 2001, PNPLA3 was initially cloned from mouse 3T3 preadipocytes as a feeding-inducible gene, therefore named adiponutrin (118). In 2004, PNPLA3 was rediscovered as IPLA2epsilon by nucleotide sequence similarity search (119). In 2006, human patatin-like phospholipases including adiponutrin were grouped to the PNPLA family (120), which has 9 members (PNPLA1-9). The common feature of the PNPLA family members is the patatin-like phospholipase domain (Figure 1).

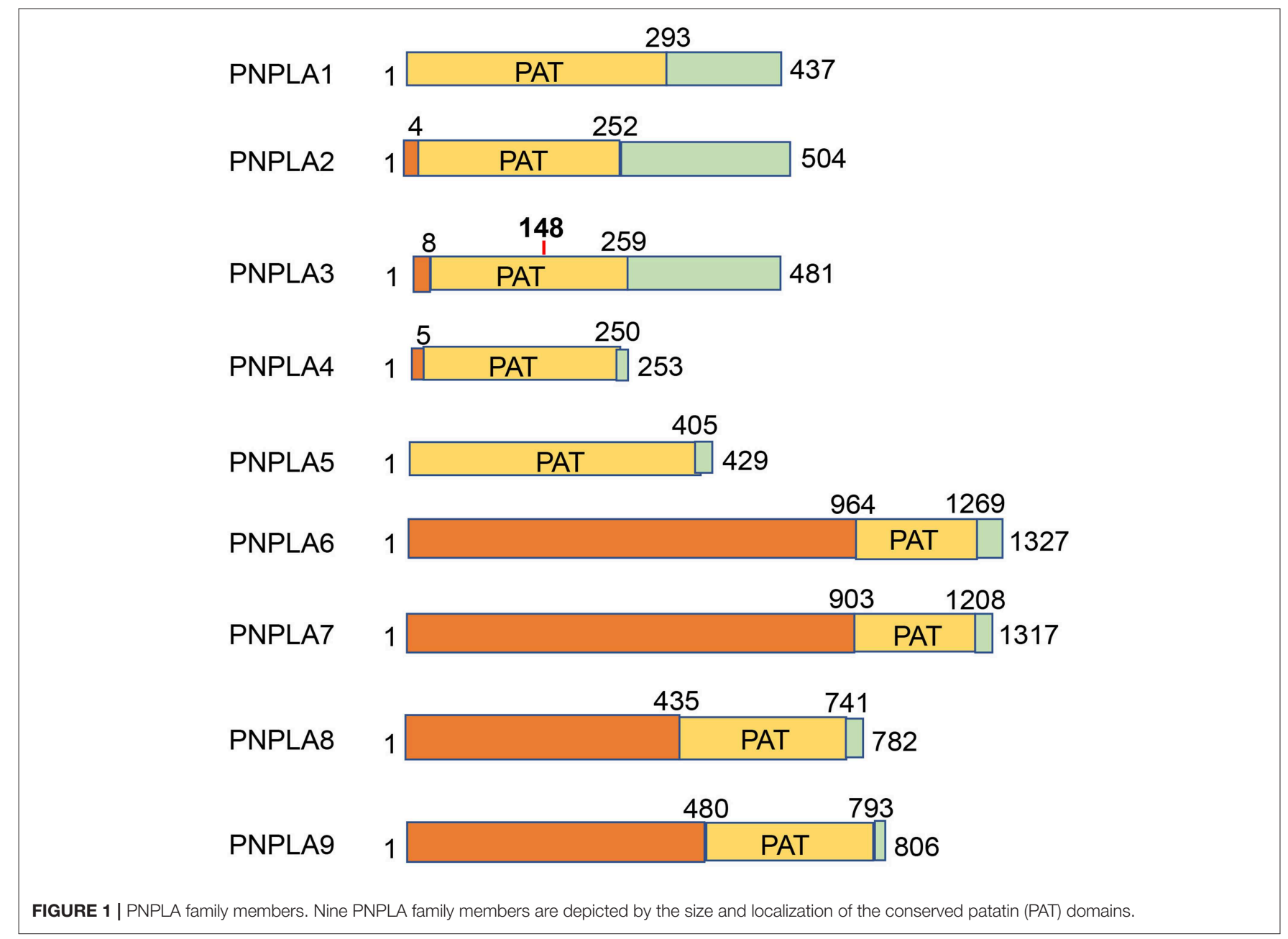


Protein sequence alignments show that the overall sequence conservation is low except a few conserved regions including the glycine-rich region and the aspartate-glycine residues of the catalytic site (120).

\section{PNPLA3 GENE CHARACTERIZATION}

Human PNPLA3 gene is localized on chromosome 22 (22q13.31). It has 9 exons that encode a 481 -amino acid protein. In contrast, mouse Pnpla3 (384 amino acids) is much smaller than human PNPLA3 protein (Figure 2), as both proteins share high homology in the N-terminal half of the amino acid sequences. But the mouse Pnpla3 lacks the middle 17 residues and the $\mathrm{C}$-terminal 75 residues in the human PNPLA3 protein. Therefore, it should be cautioned when implying the mouse Pnpla3 function to human PNPLA3. Another major difference between mouse and human PNPLA3 genes is the tissue-wise gene expression profiles. The human PNPLA3 gene is expressed highly in the liver and moderately in the adipose tissue, brain, kidney, and skin $(120,121)$; however, the mouse Pnpla3 gene is expressed at very high levels in both white and brown adipose tissues but at low levels in other tissues $(118,122)$. PNPLA3 is regulated by carbohydrate-response element binding protein (ChREBP) and sterol regulatory element binding protein 1c (SREBP1c) in mouse and human hepatocytes (123-125). Surprisingly, Pnpla3 gene knockout mice have normal levels of plasma and hepatic triglyceride contents and they do not develop fatty liver disease $(126,127)$. Interestingly, human PNPLA3(148M) transgenic mice develop hepatic steatosis on chow or high-sucrose diet (128). Pnpla3(148M) knockin mice also develop hepatic steatosis on the high-sucrose diet $(129,130)$ and hepatic inflammation and fibrosis on a NASH diet (131).

\section{PNPLA3 ENZYMATIC ACTIVITIES}

PNPLA3 has been shown to possess triacylglycerol lipase and acylglycerol transacylase activities using recombinant human PNPLA3 protein purified from Sf9 insect cells and triolein and mono-olein as substrates, respectively (119). However, when Huang et al. used similar recombinant human PNPLA3 protein from Sf9 cells to analyze lipase and transacylase activities, they only detected the lipase activity against major

\begin{tabular}{|c|c|c|c|}
\hline Human & 1 & $\begin{array}{l}\text { MYDAERGWSLSFAGCGFLGFYHVGATRCLSEHAPHLLRDARMLFGASAGALHCVGVLSGI } \\
\text { MYD ER WSLSFAGCGFLGFYHVGAT CLSE APHLLRDAR FG SAGALH V + }+\end{array}$ & 60 \\
\hline Mouse & 1 & MYDPERRWSLSFAGCGFLGFYHVGATLCLSERAPHLLRDARTFFGCSAGALHAVTFVCSL & 60 \\
\hline Human & 61 & $\begin{array}{l}\text { PLEQTLQVLSDLVRKARSRNIGIFHPSFNLSKFLRQGLCKCLPANVHQLISGKIGISLTR } \\
\mathrm{PL}++++\mathrm{L} \text { DLVRKARSRNIG HP FN }++\mathrm{K}+\mathrm{R} \text { GL }+ \text { LP NVHQ+ISGK }+ \text { ISLTR }\end{array}$ & 120 \\
\hline Mouse & 61 & PLGRIMEI LMDLVRKARSRNIGTLHPFFNINKCIRDGLQESLPDNVHQVISGKVHISLTR & 120 \\
\hline Human & 121 & $\begin{array}{l}\text { VSDGENVLVSDFRSKDEVVDALVCSCFIPFYSGLIPPSFRGVRYVDGGVSDNVPFIDAKT } \\
\text { VSDGENVLVS+F SKDEVVDALVCSCFIP +SGLIPPSFRG RYVDGGVSDNVP +DAKT }\end{array}$ & 180 \\
\hline Mouse & 121 & $\frac{\text { VSDGENVLVSEFHSKDEVVDALVCSCFIPLFSGLIPPSFRGERYVDGGVSDNVPVLDAKT }}{\star}$ & 180 \\
\hline Human & 181 & $\begin{array}{l}\text { TITVSPFYGEYDICPKVKSTNFLHVDITKLSLRLCTGNLYLLSRAFVPPDLKVLGEICLR } \\
\text { TITVSPFYGE+DICPKVKSTNF HV+IT LSLRLCTGNL LL+RA P } \quad \text { D+KV+GE+C + }\end{array}$ & 240 \\
\hline Mouse & 181 & TITVSPFYGEHDICPKVKSTNFFHVNITNLSLRLCTGNLQLLTRALFPSDVKVMGELCYQ & 240 \\
\hline Human & 241 & 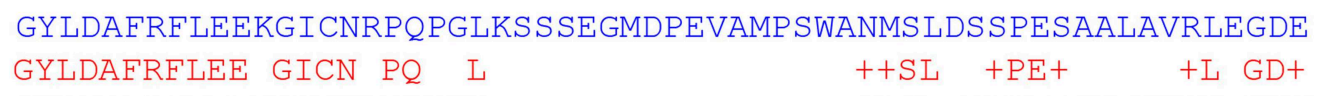 & 300 \\
\hline Mouse & 241 & GYLDAFRFLEENGICNGPQRSL---------------SLSL-VAPEACLENGKLVGDK & 282 \\
\hline Human & 301 & $\begin{array}{l}\text { LLDHLRLSILPWDESILDTLSPRLATALSEEMKDKGGYMSKICNLLPIRIMSYVMLPCTL } \\
++\mathrm{S}+\mathrm{DE}+\mathrm{I}+\mathrm{TLSP} \text { L+TALSE }+\mathrm{KD}+\mathrm{GY}+\mathrm{SK}+\mathrm{CNLLP}+\mathrm{RI}+\mathrm{SY}+\mathrm{MLPC}+\mathrm{L}\end{array}$ & 360 \\
\hline Mouse & 283 & ----VPVSLCFTDENIWETLSPELSTALSEAIKDREGYLSKVCNLLPVRILSYIMLPCSL & 338 \\
\hline Human & 361 & $\begin{array}{l}\text { PVESAIAIVQRLVTWLPDMPDDVLWLQWVTSQVETRVLMCLLPASR } \\
\text { PVESAIA V RLVTWLPD+ DD+ WLQW TSQV }\end{array}$ & .481 \\
\hline Mouse & 339 & PVESAIAAVHRLVTWLPDIQDDIQWLQWATSQVCARMTMCLLPSTR & \\
\hline
\end{tabular}


glycerolipids including triacylglyceride, diacylglyceride, and monoacylglyceride but not transacylase activity (132). In another study, human PNPLA3 was overexpressed and purified from HEK293 cells and showed to have a lipase activity on 1,2o-dilauryl-rac-glycerol-3-glutaric acid-(6'-methylresorufin) ester (122). Mutation of the active-site serine within the $\mathrm{Ser}^{47}$ Asp ${ }^{166}$ catalytic dyad motif abolished the lipase activity; however, overexpression of human PNPLA3 in HEK293 cells did not decrease the cellular triglyceride levels (122). The recombinant human PNPLA3(148M) mutant from Sf9 cells was shown to lose the triglyceride hydrolase activity using triolein as substrate (133). Human wildtype PNPLA3 but not the 148M mutant recombinant protein from yeast cells also showed triglyceride hydrolase activity (134). In addition, wildtype recombinant human PNPLA3 protein purified from yeast cells also showed retinyl esterase activity using retinyl-palmitate as substrate whereas the $148 \mathrm{M}$ mutant protein had diminished activity (135). Retinoic acids (all-trans) have been shown to activate retinoic acid receptor (RAR) and retinoid X receptor (RXR) and subsequently downregulate fibrotic genes in HSCs (136-138). PNPLA3(148M) mutant causes an decrease in retinol levels and downregulation of RAR/RXR target genes in the LX-2 hepatic stellate cell line (139).

\section{PNPLA3 IN LIPID DROPLET HOMEOSTASIS}

PNPLA3 is mostly bound to lipid droplets in mammalian cells $(133,140-142)$, but how this protein functions on lipid droplet remains elusive (Figure 3). Several lines of evidence suggest that PNPLA3(148M) abnormally accumulating on lipid droplets links to the impairment of lipid droplet metabolism. Wildtype PNPLA3 turns over according to fasting/feeding cycles; however, the $148 \mathrm{M}$ mutant PNPLA3 is resistant to ubiquitin- or autophagy-mediated protein degradation (129, 143, 144). Excess PNPLA3 on the lipid droplets seems to impair the activity of PNPLA2, also called adipose triglyceride lipase (ATGL), likely through competing with the ATGL activator -comparative gene identification 58 (CGI-58) or officially abhydrolase domain containing 5 (ABHD5) $(140,142,145)$. Some data suggest that PNPLA3(148M) tends to interact with CGI-58 more strongly than the wildtype counterpart does (145). CGI-58 is also required for the targeting of PNPLA3 to lipid droplet since PNPLA3 cannot localize onto lipid droplet in the CGI-58 knockout liver cells (140).

\section{PNPLA3 IN HEPATIC FIBROSIS}

In addition to hepatocytes, human PNPLA3 gene is also abundantly expressed in HSCs $(121,139)$. PNPLA3 can be induced by TGF- $\beta$ but not platelet-derived growth factor (PDGF) in human HSCs (146). The same report also shows that overexpression of the wildtype PNPLA3 but not the PNPLA3(148M) mutant reduces the intracellular retinyl esters in HSCs. Interestingly, after incubation with retinol and palmitate, wildtype, but not mutant PNPLA3 decreases the secretion

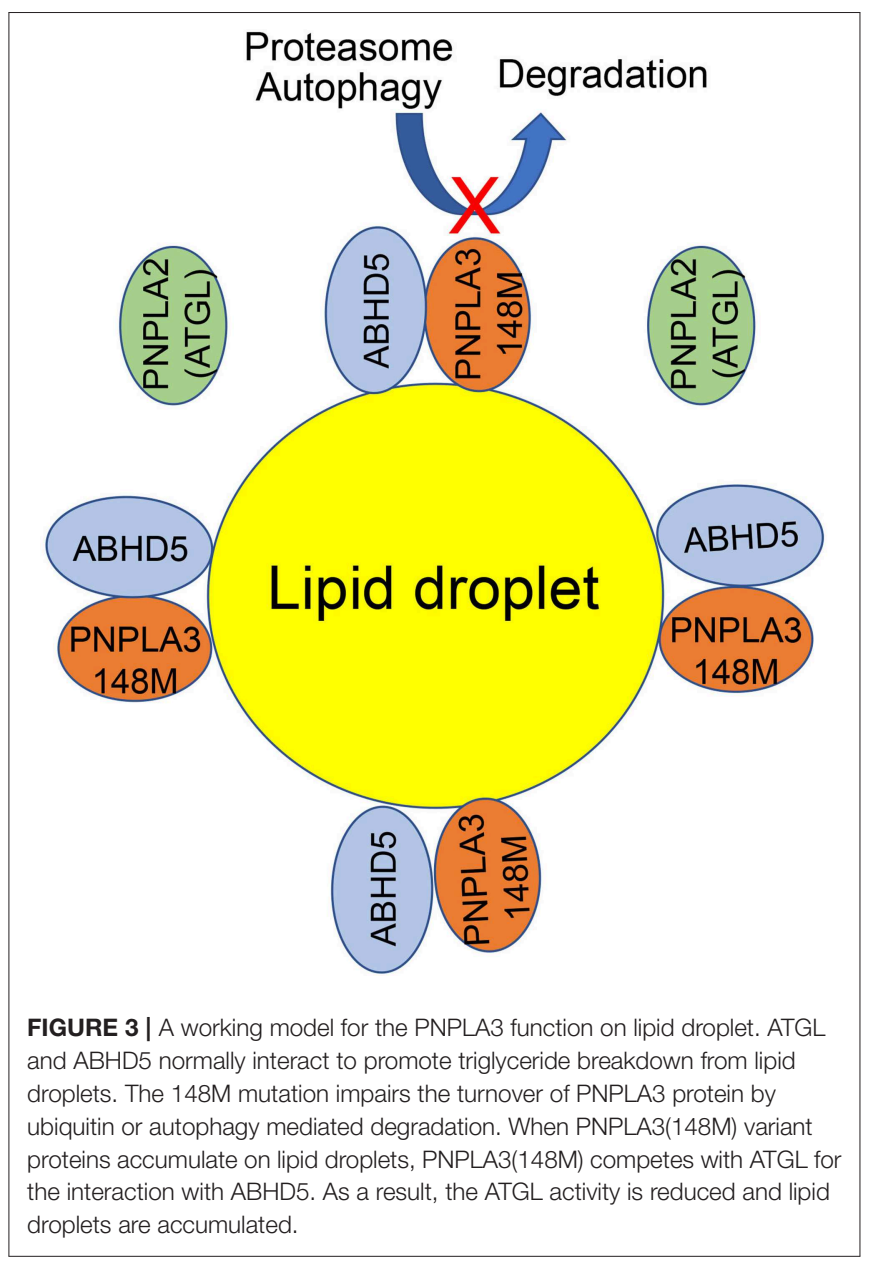

of matrix metallopeptidase 2 (MMP2), tissue inhibitor of metalloproteinase 1 (TIMP1), and TIMP2 from HSCs (146). Another report shows that the PNPLA3 gene expression is induced during the primary human HSC activation and knockdown of PNPLA3 by siRNA attenuates the HSC activation (139). Human HSCs with the PNPLA3(148M) variant have higher expression of inflammatory cytokines and chemokines including granulocyte-macrophage colony-stimulating factor (GM-CSF), chemokine (C-X-C motif) ligand 8 (CXCL8), and TGF- $\beta$. Overexpression of the PNPLA3(148M) variant enhances the HSC proliferation and chemotaxis (139). In contrast to the previous report regarding the retinyl palmitate lipase activity of PNPLA3 (135), Bruschi et al. have found that total retinol content and RXR and RAR signaling are both lower in the PNPLA3(148M) mutant HSCs than that in the PNPLA3 wildtype HSCs (139). Further signaling analysis has revealed that c-Jun $\mathrm{N}$-terminal kinase (JNK) is highly activated in the PNPLA3(148M) HSCs. As a consequence, peroxisome proliferator-activated receptor gamma (PPAR $\gamma)$, a key HSC quiescence regulator, is inhibited, whereas activator protein 1 (AP-1), a proinflammatory transcription factor, is activated (139). Collectively, these dysregulations contribute to the fibrogenic phenotype in the PNPLA3(148M) HSCs. The inhibition of 
TABLE 1 | Human PNPLA3 genetic association studies in liver diseases.

\begin{tabular}{|c|c|c|c|}
\hline PNPLA3 SNP & Study population & Associated phenotype and significance & References \\
\hline rs738409[G] & $\begin{array}{l}\text { Hispanics, African Americans, European } \\
\text { Americans, } N=9,229\end{array}$ & $\begin{array}{l}\text { Positive association with hepatic fat content }\left(P=5.9 \times 10^{-10}\right) \text {, serum } \\
\operatorname{ALT}\left(P=1.3 \times 10^{-5} \text { in Hispanics }\right)\end{array}$ & $(65)$ \\
\hline $\begin{array}{l}\text { rs2281135[A], } \\
\text { rs738409[G] }\end{array}$ & Europeans, $N=12,419$ & Positive association with $\mathrm{ALT}\left(P=8.4 \times 10^{-16}, P=3.7 \times 10^{-10}\right)$ & $(110)$ \\
\hline rs738409[G] & West-Eurasian populations, $N=23,274$ & $\begin{array}{l}\text { Negative association with total cholesterol }\left(P=8.87 \times 10^{-7}\right) \text {, non-HDL } \\
\text { cholesterol }\left(P=2.27 \times 10^{-6}\right), \mathrm{LDL} \text { cholesterol }\left(P=7.99 \times 10^{-4}\right)\end{array}$ & $(148)$ \\
\hline rs738409[G] & $\begin{array}{l}\text { Mestizo (mixed European and Native American } \\
\text { ancestry), } N=1,221\end{array}$ & $\begin{array}{l}\text { Positive association with } \operatorname{ALD}\left(\mathrm{OR}=1.45, P=8.4 \times 10^{-4}\right) \text { and alcoholic } \\
\text { liver cirrhosis }\left(\mathrm{OR}=2.25, P=1.7 \times 10^{-10}\right)\end{array}$ & (89) \\
\hline rs738409[G] & $\begin{array}{l}\text { Caucasian (82.1\%), African American (2.3\%), } \\
\text { Asian (5.4\%), American Indian (3.2\%), other } \\
(7 \%), N=1,117\end{array}$ & $\begin{array}{l}\text { Positive association with hepatic steatosis }(\mathrm{OR}=1.46, P=0.03) \text {, portal } \\
\text { inflammation }\left(\mathrm{OR}=1.57, P=2.5 \times 10^{-4}\right) \text {, lobular inflammation }(\mathrm{OR}= \\
1.84, P=0.005) \text {, Mallory-Denk bodies }(\mathrm{OR}=1.6, P=0.015) \text {, NAFLD } \\
\text { activity score }(P=0.004) \text {, hepatic fibrosis }\left(\mathrm{OR}=1.5, P=7.7 \times 10^{-6}\right)\end{array}$ & $(68)$ \\
\hline rs738409[G] & Japanese, $N=831$ & Positive association with NAFLD $\left(\mathrm{OR}=1.73, P=9.4 \times 10^{-10}\right)$ & $(149)$ \\
\hline rs738409[G] & German, $N=1,419$ & $\begin{array}{l}\text { Positive association with alcoholic liver cirrhosis }(\mathrm{OR}=2.79, P=1.6 \times \\
\left.10^{-6}\right)\end{array}$ & $(84)$ \\
\hline rs738409[G] & Americans and Europeans, $N=1,997$ & Positive association with NAFLD $\left(\mathrm{OR}=3.26, P=3.6 \times 10^{-43}\right)$ & (83) \\
\hline rs738409[G] & European Caucasians, $N=537$ & $\begin{array}{l}\text { Positive association with chronic hepatitis } C \text { related hepatic steatosis (OR } \\
=2.55, P=0.034) \text {, fibrosis }(\mathrm{OR}=3.13, P=0.002)\end{array}$ & (94) \\
\hline rs738409[G] & German, $N=899$ & Positive association with liver cirrhosis $(\mathrm{OR}=1.56, P=0.005)$ & $(150)$ \\
\hline rs738409[G] & European Caucasians, $N=658$ & Positive association with liver cirrhosis $(\mathrm{OR}=2.08, P=0.02)$ & $(91)$ \\
\hline rs738409[G] & Japanese, $N=1,326$ & Positive association with NAFLD $\left(\mathrm{OR}=2.05, P=6.8 \times 10^{-14}\right)$ & $(151)$ \\
\hline rs738409[G] & $\begin{array}{l}\text { American Caucasians, African Americans, } \\
\text { Mexican Americans, } N=4,804\end{array}$ & $\begin{array}{l}\text { Positive association with hepatic steatosis and high ALT }(O R=1.36, P= \\
0.01)\end{array}$ & $(152)$ \\
\hline rs738409[G] & American Caucasians, $N=751$ & Positive association with $\mathrm{HCC}(\mathrm{OR}=3.21, P=0.02)$ & $(153)$ \\
\hline rs738409[G] & European Caucasians, $N=2,138$ & $\begin{array}{l}\text { Positive association with alcoholic liver cirrhosis }(\mathrm{OR}=2.19, P=1.54 \times \\
\left.10^{-48}\right)\end{array}$ & $(42)$ \\
\hline rs738409[G] & Chinese Han, $N=768$ & Positive association with NAFLD $\left(\mathrm{OR}=1.52, P=8.7 \times 10^{-4}\right)$ & $(102)$ \\
\hline rs738409[G] & Eastern European, $N=969$ & $\begin{array}{l}\text { Positive association with liver fibrosis }(\mathrm{OR}=1.65, P=0.001) \text {, liver } \\
\text { cirrhosis }\left(\mathrm{OR}=1.92, P=5.57 \times 10^{-7}\right)\end{array}$ & $(154)$ \\
\hline rs738409[G] & European Caucasians, $N=183$ & Positive association with alcoholic hepatitis $(\mathrm{OR}=1.9, P=0.01)$ & $(155)$ \\
\hline rs738409[G] & Korean, $N=4,409$ & Positive association with NAFLD $\left(\mathrm{OR}=1.54, P=1.74 \times 10^{-15}\right)$ & $(156)$ \\
\hline rs738409[G] & Chinese Han, $N=1,152$ & Positive association with ALD $\left(O R=1.93, P=6.25 \times 10^{-14}\right)$ & $(115)$ \\
\hline rs738409[G] & Europeans, $N=5,525$ & $\begin{array}{l}\text { Positive association with } \mathrm{HCC}(\mathrm{OR}=1.67, P=0.005), \mathrm{HCC} \text { in ALD } \\
\text { patients }\left(\mathrm{OR}=3.91, P=1.14 \times 10^{-9}\right), \mathrm{HCC} \text { in non-fibrotic patients (OR } \\
=2.19, P=0.007)\end{array}$ & $(106)$ \\
\hline rs738409[G] & American Caucasians, $N=9,677$ & Positive association with NAFLD $\left(O R=1.79, P=1.7 \times 10^{-20}\right)$ & $(157)$ \\
\hline $\begin{array}{l}\text { rs4823173[A], } \\
\text { rs2896019[G], } \\
\text { rs2281135[A] }\end{array}$ & Mexican Americans, $N=3,757$ & $\begin{array}{l}\text { Positive association with AST }\left(P=3.44 \times 10^{-10}, P=7.29 \times 10^{-9}, P=\right. \\
\left.8.73 \times 10^{-9}\right)\end{array}$ & $(109)$ \\
\hline
\end{tabular}

PPAR $\gamma$ in the PNPLA3(148M) HSCs also negatively affects the liver $\mathrm{X}$ receptor alpha $(\mathrm{LXR} \alpha)$ activity. As a result, cholesterol is accumulated in those mutant HSCs, and this also contributes to the inflammation and fibrogenesis in the PNPLA3(148M) HSCs (147).

\section{PNPLA3 GENE POLYMORPHISM AND CHRONIC LIVER DISEASE}

Alcoholic and non-alcoholic liver diseases often begin with simple steatosis and progress to hepatitis, fibrosis/cirrhosis, and even liver cancer. Both environmental and genetic factors contribute to the development of these chronic liver diseases. Among the well documented genes, PNPLA3 has the broad impact on ALD and NAFLD. The involvement of PNPLA3 variant rs738409 (148 M) in the broad spectrum of chronic liver disease has been shown by numerous GWAS (see Table 1). In 2008, Romeo et al. identified a strong association between the PNPLA3(148M) variant and hepatic fat concentration in a GWAS on Hispanic, African American, and European American individuals (65). The 148M variant frequencies are concordant with the prevalence of NAFLD in these three ancestry groups, and their allele frequencies are: Hispanics (0.49), European Americans (0.23), and African Americans (0.17). Since then, multiple GWASs have reported a strong association of PNPLA3(148M) variant with both ALD and NAFLD (Table 1 and Figure 4). Several studies have documented a strong association of the $148 \mathrm{M}$ variant with liver cirrhosis $(42,76,154,158-160)$. A number of 


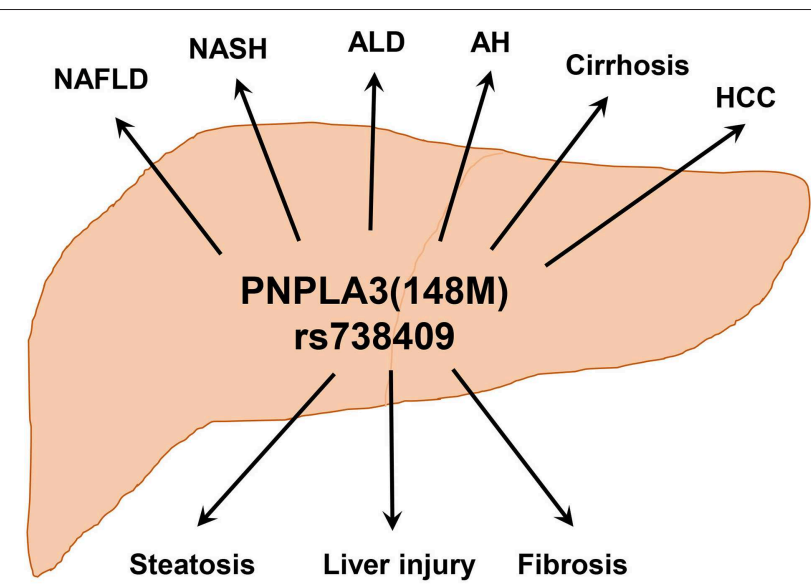

FIGURE 4 | PNPLA3(148M) is associated with a wide-spectrum of chronic liver diseases. Hepatic accumulation of PNPLA3(148M) protein leads to triglyceride accumulation, liver injury, and fibrosis. With different etiologies, this may lead to the development of various liver disorders including NAFLD, $\mathrm{NASH}, \mathrm{ALD}$, alcoholic hepatitis (AH), cirrhosis, and HCC.

reports have also shown that the $148 \mathrm{M}$ variant is also associated with higher risk for $\operatorname{HCC}(77,85,92,93,106$, $108,153,160-169)$. In addition, the PNPLA3 variant rs738409 could lead to differential gene regulation via microRNAs. An in silico analysis has identified hsa-miR-769-3p and hsa-miR516a-3p as potential microRNAs targeting the 3' UTR of the human PNPLA3 mRNA (170). Experimental validations are needed to demonstrate their functional relevance to the PNPLA3(148M) variant.

\section{THERAPEUTIC STRATEGIES FOR TARGETING PNPLA3 FOR PERSONIZED TREATMENT OF CHRONIC LIVER DISEASE}

As the PNPLA3(148M) variant is quite prevalent in most populations, especially among Hispanics (65), it is very significant to develop therapeutics targeting this genetic polymorphism. According to the PNPLA3(148M) biology, there are several potential ways of targeting the $148 \mathrm{M}$ variant. First, the PNPLA3(148M) variant can be targeted at the RNA levels by small interfering RNA (siRNA), small hairpin RNA (shRNA), or antisense RNA oligonucleotide. A recent report has shown that triantennary $\mathrm{N}$-acetylgalactosamine $\left(\right.$ GalNAC $_{3}$ ) conjugated antisense oligonucleotides (ASO) targeting Pnpla3 in a $148 \mathrm{M}$ knockin mouse model significantly reduce hepatic steatosis, inflammation, and fibrosis (131), suggesting the utility of the ASO strategy. In another report, targeting Pnpla3 in the

\section{REFERENCES}

1. Younossi Z, Tacke F, Arrese M, Sharma BC, Mostafa I, Bugianesi E, et al. Global perspectives on non-alcoholic fatty liver disease and nonalcoholic steatohepatitis. Hepatology. (2018) 69:2672-82. doi: 10.1002/hep. 30251
148M knockin mice by AAV-mediated shRNA has also showed effective reduction of hepatic triglyceride contents (143). For the translational perspective, PNPLA3(148M)-allele-specific RNAi is preferred for human patients in order to avoid affecting the PNPLA3 wildtype allele as we do not fully understand the PNPLA3 biology. With the encouraging phase III clinical trial data on proprotein convertase subtilisin/kexin type 9 (PCSK9) RNAi (171), targeting the PNPLA3(148M) variant by RNAi can be an attractive strategy. Second, PNPLA3 can be targeted at the protein level. Recent data suggested that an accumulation of PNPLA3(148M) on lipid droplets is very critical for the pathogenesis of fatty liver disease $(129,130,140,143)$. Therefore, targeting PNPLA3(148M) for degradation can be a useful strategy. Recently, a proof-of-concept study using proteolysis-targeting chimera (PROTAC)-mediated degradation of Halo-tagged PNPLA3(148M) has shown a significant effect on lowering hepatic triglyceride content (143). The question will be how to degrade endogenous PNPLA3(148M) protein in a variant-specific manner. To date, there are no effective ways to specifically target the PNPLA3(148M) mutant protein. However, targeting PNPLA3 may work from another angle - an interaction between PNPLA3 and CGI-58, as the interaction can be regulated by fatty acids or synthetic CGI-58 ligands (145). Taken together, targeting PNPLA3(148M) has been increasingly appreciated for therapeutic development for multiple chronic liver diseases including ALD and NASH.

In summary, PNPLA3 is an enigmatic protein that has broad implications in metabolic liver diseases from simple steatosis to cirrhosis and liver cancer. Better understanding the biological function of PNPLA3 in lipid droplet metabolism should facilitate the therapeutic development. Targeting the PNPLA3(148M) variant is expected to be an excellent example of the modern personalized medicine.

\section{AUTHOR CONTRIBUTIONS}

$\mathrm{XD}$ conceived the idea, gathered the data, and wrote the manuscript.

\section{FUNDING}

This work was supported in part by the US National Institutes of Health (National Institute on Alcohol Abuse and Alcoholism R21AA024550 to XD; National Institute of Diabetes and Digestive and Kidney Diseases R01DK107682 to XD and R56DK091592 to XD and P30DK097512 to Indiana Diabetes Research Center; National Center for Advancing Translational Sciences UL1TR002529 to Indiana Clinical and Translational Sciences Institute).
2. Friedman SL, Neuschwander-Tetri BA, Rinella M, Sanyal AJ. Mechanisms of NAFLD development and therapeutic strategies. Nat Med. (2018) 24:908-22. doi: 10.1038/s41591-018-0104-9

3. Seitz HK, Bataller R, Cortez-Pinto H, Gao B, Gual A, Lackner C, et al. Alcoholic liver disease. Nat Rev Dis Primers. (2018) 4:16. doi: 10.1038/s41572-018-0014-7 
4. Hydes T, Gilmore W, Sheron N, Gilmore I. Treating alcohol-related liver disease from a public health perspective. J Hepatol. (2019) 70:223-36. doi: 10.1016/j.jhep.2018.10.036

5. Stefan N, Haring HU, Cusi K. Non-alcoholic fatty liver disease: causes, diagnosis, cardiometabolic consequences, and treatment strategies. Lancet Diabetes Endocrinol. (2019) 7:313-324. doi: 10.1016/S2213-8587(18) 30154-2

6. Manne V, Handa P, Kowdley KV. Pathophysiology of nonalcoholic fatty liver disease/nonalcoholic steatohepatitis. Clin Liver Dis. (2018) 22:23-37. doi: 10.1016/j.cld.2017.08.007

7. Eslam M, Valenti L, Romeo S. Genetics and epigenetics of NAFLD and NASH: clinical impact. J Hepatol. (2018) 68:268-79. doi: 10.1016/j.jhep.2017.09.003

8. Eslam M, George J. Genetic contributions to NAFLD: leveraging shared genetics to uncover systems biology. Nat Rev Gastroenterol Hepatol. (2019). doi: 10.1038/s41575-019-0212-0. [Epub ahead of print].

9. Mahdessian H, Taxiarchis A, Popov S, Silveira A, Franco-Cereceda A, Hamsten A, et al. TM6SF2 is a regulator of liver fat metabolism influencing triglyceride secretion and hepatic lipid droplet content. Proc Natl Acad Sci USA. (2014) 111:8913-8. doi: 10.1073/pnas.1323785111

10. Fan $\mathrm{Y}, \mathrm{Lu} \mathrm{H}$, Guo $\mathrm{Y}$, Zhu T, Garcia-Barrio MT, Jiang $\mathrm{Z}$, et al. Hepatic Transmembrane 6 superfamily member 2 regulates cholesterol metabolism in mice. Gastroenterology. (2016) 150:1208-18. doi: 10.1053/j.gastro.2016.01.005

11. Smagris E, Gilyard S, BasuRay S, Cohen JC, Hobbs HH. Inactivation of Tm6sf2, a gene defective in fatty liver disease, impairs lipidation but not secretion of very low density lipoproteins. J Biol Chem. (2016) 291:10659-76. doi: 10.1074/jbc.M116.719955

12. Ehrhardt N, Doche ME, Chen S, Mao HZ, Walsh MT, Bedoya C, et al. Hepatic Tm6sf2 overexpression affects cellular ApoB-trafficking, plasma lipid levels, hepatic steatosis and atherosclerosis. Hum Mol Genet. (2017) 26:2719-31. doi: $10.1093 / \mathrm{hmg} / \mathrm{ddx} 159$

13. Luukkonen PK, Zhou Y, Nidhina Haridas PA, Dwivedi OP, Hyotylainen T, Ali A, et al. Impaired hepatic lipid synthesis from polyunsaturated fatty acids in TM6SF2 E167K variant carriers with NAFLD. J Hepatol. (2017) 67:128-36. doi: 10.1016/j.jhep.2017.02.014

14. Musso G, Cipolla U, Cassader M, Pinach S, Saba F, De Michieli F, et al. TM6SF2 rs58542926 variant affects postprandial lipoprotein metabolism and glucose homeostasis in NAFLD. J Lipid Res. (2017) 58:1221-9. doi: 10.1194/jlr.M075028

15. O'Hare EA, Yang R, Yerges-Armstrong LM, Sreenivasan U, McFarland R, Leitch CC, et al. TM6SF2 rs58542926 impacts lipid processing in liver and small intestine. Hepatology. (2017) 65:1526-42. doi: 10.1002/hep.29021

16. Kozlitina J, Smagris E, Stender S, Nordestgaard BG, Zhou HH, TybjaergHansen A, et al. Exome-wide association study identifies a TM6SF2 variant that confers susceptibility to nonalcoholic fatty liver disease. Nat Genet. (2014) 46:352-6. doi: 10.1038/ng.2901

17. Milano M, Aghemo A, Mancina RM, Fischer J, Dongiovanni P, De Nicola S, et al. Transmembrane 6 superfamily member 2 gene E167K variant impacts on steatosis and liver damage in chronic hepatitis C patients. Hepatology. (2015) 62:111-7. doi: 10.1002/hep.27811

18. Pirola CJ, Sookoian S. The dual and opposite role of the TM6SF2-rs58542926 variant in protecting against cardiovascular disease and conferring risk for nonalcoholic fatty liver: a meta-analysis. Hepatology. (2015) 62:1742-56. doi: 10.1002/hep. 28142

19. Sookoian S, Castano GO, Scian R, Mallardi P, Fernandez Gianotti T, Burgueno AL, et al. Genetic variation in transmembrane 6 superfamily member 2 and the risk of nonalcoholic fatty liver disease and histological disease severity. Hepatology. (2015) 61:515-25. doi: 10.1002/hep.27556

20. Wang X, Liu Z, Peng Z, Liu W. The TM6SF2 rs58542926 T allele is significantly associated with non-alcoholic fatty liver disease in Chinese. $J$ Hepatol. (2015) 62:1438-9. doi: 10.1016/j.jhep.2015.01.040

21. Eslam M, Mangia A, Berg T, Chan HL, Irving WL, Dore GJ, et al. Diverse impacts of the rs58542926 E167K variant in TM6SF2 on viral and metabolic liver disease phenotypes. Hepatology. (2016) 64:34-46. doi: 10.1002/hep. 28475

22. Goffredo M, Caprio S, Feldstein AE, D'Adamo E, Shaw MM, Pierpont B, et al. Role of TM6SF2 rs58542926 in the pathogenesis of nonalcoholic pediatric fatty liver disease: a multiethnic study. Hepatology. (2016) 63:117-125. doi: $10.1002 /$ hep. 28283

23. Grandone A, Cozzolino D, Marzuillo P, Cirillo G, Di Sessa A, Ruggiero L, et al. TM6SF2 Glu167Lys polymorphism is associated with low levels of LDL-cholesterol and increased liver injury in obese children. Pediatr Obes. (2016) 11:115-9. doi: 10.1111/ijpo.12032

24. Mancina RM, Sentinelli F, Incani M, Bertoccini L, Russo C, Romeo S, et al. Transmembrane-6 superfamily member 2. (TM6SF2) E167K variant increases susceptibility to hepatic steatosis in obese children. Dig Liver Dis. (2016) 48:100-101. doi: 10.1016/j.dld.2015.10.003

25. Viitasalo A, Pihlajamaki J, Pananen J, Atalay M, Lindi V, Lakka TA. Associations of TM6SF2 167K allele with liver enzymes and lipid profile in children: the PANIC Study. Pediatr Res. (2016) 79:684-8. doi: 10.1038/pr.2016.3

26. Brown KS, Kalinowski SS, Megill JR, Durham SK, Mookhtiar KA. Glucokinase regulatory protein may interact with glucokinase in the hepatocyte nucleus. Diabetes. (1997) 46:179-86. doi: $10.2337 /$ diabetes.46.2.179

27. Lin YC, Chang PF, Chang MH, Ni YH. Genetic variants in GCKR and PNPLA3 confer susceptibility to nonalcoholic fatty liver disease in obese individuals. Am J Clin Nutr. (2014) 99:869-74. doi: 10.3945/ajcn.113. 079749

28. Tam CH, Ma RC, So WY, Wang Y, Lam VK, Germer S, et al. Interaction effect of genetic polymorphisms in glucokinase. (GCK) and glucokinase regulatory protein. (GCKR) on metabolic traits in healthy Chinese adults and adolescents. Diabetes. (2009) 58:765-9. doi: 10.2337/db08-1277

29. Yang Z, Wen J, Tao X, Lu B, Du Y, Wang M, et al. Genetic variation in the GCKR gene is associated with non-alcoholic fatty liver disease in Chinese people. Mol Biol Rep. (2011) 38:1145-50. doi: 10.1007/s11033-010-0212-1

30. Zain SM, Mohamed Z, Mohamed R. Common variant in the glucokinase regulatory gene rs780094 and risk of nonalcoholic fatty liver disease: a metaanalysis. J Gastroenterol Hepatol. (2015) 30:21-7. doi: 10.1111/jgh.12714

31. Petit JM, Masson D, Guiu B, Rollot F, Duvillard L, Bouillet B, et al. GCKR polymorphism influences liver fat content in patients with type 2 diabetes. Acta Diabetol. (2016) 53:237-42. doi: 10.1007/s00592-015-0766-4

32. Santoro N, Caprio S, Pierpont B, Van Name M, Savoye M, Parks EJ. Hepatic de novo lipogenesis in obese youth is modulated by a common variant in the GCKR gene. J Clin Endocrinol Metab. (2015) 100:E1125-32. doi: $10.1210 /$ jc. $2015-1587$

33. Santoro N, Feldstein AE, Enoksson E, Pierpont B, Kursawe R, Kim G, et al. The association between hepatic fat content and liver injury in obese children and adolescents: effects of ethnicity, insulin resistance, and common gene variants. Diabetes Care. (2013) 36:1353-60. doi: 10.2337/dc12-1791

34. Santoro N, Zhang CK, Zhao H, Pakstis AJ, Kim G, Kursawe R, et al. Variant in the glucokinase regulatory protein. (GCKR) gene is associated with fatty liver in obese children and adolescents. Hepatology. (2012) 55:781-9. doi: $10.1002 /$ hep. 24806

35. Simons N, Dekker JM, van Greevenbroek MM, Nijpels G, t Hart LM, van der Kallen CJ, et al. A common gene variant in glucokinase regulatory protein interacts with glucose metabolism on diabetic dyslipidemia: the combined CODAM and hoorn studies. Diabetes Care. (2016) 39:1811-7. doi: $10.2337 /$ dc16-0153

36. Sliz E, Sebert S, Wurtz P, Kangas AJ, Soininen P, Lehtimaki T, et al. NAFLD risk alleles in PNPLA3, TM6SF2, GCKR and LYPLAL1 show divergent metabolic effects. Hum Mol Genet. (2018) 27:2214-23. doi: $10.1093 / \mathrm{hmg} / \mathrm{ddy} 124$

37. Tan HL, Zain SM, Mohamed R, Rampal S, Chin KF, Basu RC, et al. Association of glucokinase regulatory gene polymorphisms with risk and severity of non-alcoholic fatty liver disease: an interaction study with adiponutrin gene. J Gastroenterol. (2014) 49:1056-64. doi: $10.1007 / \mathrm{s} 00535-013-0850-\mathrm{x}$

38. Trico D, Caprio S, Rosaria Umano G, Pierpont B, Nouws J, Galderisi A, et al. Metabolic features of nonalcoholic fatty liver. (NAFL) in obese adolescents: findings from a multiethnic cohort. Hepatology. (2018) 68:137690. doi: 10.1002/hep.30035

39. Caddeo A, Jamialahmadi O, Solinas G, Pujia A, Mancina RM, Pingitore $\mathrm{P}$, et al. MBOAT7 is anchored to endomembranes by six transmembrane domains. J Struct Biol. (2019) 206:349-60. doi: 10.1016/j.jsb.2019.04.006 
40. Lee HC, Inoue $\mathrm{T}$, Sasaki J, Kubo $\mathrm{T}$, Matsuda $\mathrm{S}$, Nakasaki Y, et al. LPIAT1 regulates arachidonic acid content in phosphatidylinositol and is required for cortical lamination in mice. Mol Biol Cell. (2012) 23:4689-700. doi: 10.1091/mbc.e12-09-0673

41. Basyte-Bacevice V, Skieceviciene J, Valantiene I, Sumskiene J, Petrenkiene V, Kondrackiene J, et al. TM6SF2 and MBOAT7 gene variants in liver fibrosis and cirrhosis. Int J Mol Sci. (2019) 20:1277. doi: 10.3390/ijms20061277

42. Buch S, Stickel F, Trepo E, Way M, Herrmann A, Nischalke HD, et al. A genome-wide association study confirms PNPLA3 and identifies TM6SF2 and MBOAT7 as risk loci for alcohol-related cirrhosis. Nat Genet. (2015) 47:1443-8. doi: 10.1038/ng.3417

43. Di Sessa A, Umano GR, Cirillo G, Del Prete A, Iacomino R, Marzuillo P, et al. The membrane-bound O-acyltransferase7 rs641738 variant in pediatric nonalcoholic fatty liver disease. J Pediatr Gastroenterol Nutr. (2018) 67:6974. doi: 10.1097/MPG.0000000000001979

44. Dursun A, Yalnizoglu D, Ozgul RK, Karli Oguz K, Yucel-Yilmaz D. Clinical highlights of a very rare phospolipid remodeling disease due to MBOAT7 gene defect. Am J Med Genet B Neuropsychiatr Genet. (2019) 183:3-4. doi: 10.1002/ajmg.b.32762

45. Helsley RN, Varadharajan V, Brown AL, Gromovsky AD, Schugar RC, Ramachandiran I, et al. Obesity-linked suppression of membrane-bound Oacyltransferase 7. (MBOAT7) drives non-alcoholic fatty liver disease. Elife. (2019) 8:e49882. doi: 10.7554/eLife.49882

46. Krawczyk M, Rau M, Schattenberg JM, Bantel H, Pathil A, Demir M, et al. Combined effects of the PNPLA3 rs738409, TM6SF2 rs58542926, and MBOAT7 rs641738 variants on NAFLD severity: a multicenter biopsy-based study. J Lipid Res. (2017) 58:247-55. doi: 10.1194/jlr.P067454

47. Luukkonen PK, Zhou Y, Hyotylainen T, Leivonen M, Arola J, Orho-Melander $\mathrm{M}$, et al. The MBOAT7 variant rs641738 alters hepatic phosphatidylinositols and increases severity of non-alcoholic fatty liver disease in humans. $J$ Hepatol. (2016) 65:1263-5. doi: 10.1016/j.jhep.2016.07.045

48. Mancina RM, Dongiovanni P, Petta S, Pingitore P, Meroni M, Rametta R, et al. The MBOAT7-TMC4 variant rs641738 increases risk of nonalcoholic fatty liver disease in individuals of european descent. Gastroenterology. (2016) 150:1219-30.e1216. doi: 10.1053/j.gastro.2016.01.032

49. Thabet K, Asimakopoulos A, Shojaei M, Romero-Gomez M, Mangia A, Irving WL, et al. MBOAT7 rs641738 increases risk of liver inflammation and transition to fibrosis in chronic hepatitis C. Nat Commun. (2016) 7:12757. doi: 10.1038/ncomms12757

50. Thabet K, Chan HLY, Petta S, Mangia A, Berg T, Boonstra A, et al. The membrane-bound O-acyltransferase domain-containing 7 variant rs641738 increases inflammation and fibrosis in chronic hepatitis B. Hepatology. (2017) 65:1840-50. doi: 10.1002/hep.29064

51. Umano GR, Caprio S, Di Sessa A, Chalasani N, Dykas DJ, Pierpont B, et al. The rs626283 Variant in the MBOAT7 gene is associated with insulin resistance and fatty liver in caucasian obese youth. Am J Gastroenterol. (2018) 113:376-83. doi: 10.1038/ajg.2018.1

52. Viitasalo A, Eloranta AM, Atalay M, Romeo S, Pihlajamaki J, Lakka TA. Association of MBOAT7 gene variant with plasma ALT levels in children: the PANIC study. Pediatr Res. (2016) 80:651-5. doi: 10.1038/pr.2016.139

53. Xia Y, Huang CX, Li GY, Chen KH, Han L, Tang L, et al. Meta-analysis of the association between MBOAT7 rs641738, TM6SF2 rs58542926 and nonalcoholic fatty liver disease susceptibility. Clin Res Hepatol Gastroenterol. (2019) 43:533-41. doi: 10.1016/j.clinre.2019.01.008

54. Yalnizoglu D, Ozgul RK, Oguz KK, Ozer B, Yucel-Yilmaz D, Gurbuz $\mathrm{B}$, et al. Expanding the phenotype of phospholipid remodelling disease due to MBOAT7 gene defect. J Inherit Metab Dis. (2019) 42:381-8. doi: 10.1002/jimd.12016

55. Ma Y, Belyaeva OV, Brown PM, Fujita K, Valles K, Karki S, et al. 17beta hydroxysteroid dehydrogenase 13 is a hepatic retinol dehydrogenase associated with histological features of nonalcoholic fatty liver disease. Hepatology. (2019) 69:1504-19. doi: 10.1002/hep.30350

56. About F, Abel L, Cobat A. HCV-associated liver fibrosis and HSD17B13. N Engl J Med. (2018) 379:1875-6. doi: 10.1056/NEJMc1804638

57. Abul-Husn NS, Cheng X, Li AH, Xin Y, Schurmann C, Stevis P, et al. A protein-truncating HSD17B13 variant and protection from chronic liver disease. N Engl J Med. (2018) 378:1096-106. doi: 10.1056/nejmoa 1712191
58. Basyte-Bacevice V, Skieceviciene J, Valantiene I, Sumskiene J, Petrenkiene V, Kondrackiene J, et al. SERPINA1 and HSD17B13 gene variants in patients with liver fibrosis and cirrhosis. J Gastrointestin Liver Dis. (2019) 28:297-302. doi: 10.15403/jgld-168

59. Chen J, Zhuo JY, Yang F, Liu ZK, Zhou L, Xie HY, et al. 17-betahydroxysteroid dehydrogenase 13 inhibits the progression and recurrence of hepatocellular carcinoma. Hepatobil Pancreat Dis Int. (2018) 17:220-6. doi: 10.1016/j.hbpd.2018.04.006

60. Gellert-Kristensen H, Nordestgaard BG, Tybjaerg-Hansen A, Stender S. High risk of fatty liver disease amplifies the alanine transaminase-lowering effect of a HSD17B13 variant. Hepatology. (2019). doi: 10.1002/hep.30799. [Epub ahead of print].

61. Kozlitina J, Stender S, Hobbs HH, Cohen JC. HSD17B13 and chronic liver disease in blacks and hispanics. N Engl J Med. (2018) 379:1876-7. doi: 10.1056/NEJMc1804027

62. Pirola CJ, Garaycoechea M, Flichman D, Arrese M, San Martino J, Gazzi C, et al. Splice variant rs72613567 prevents worst histologic outcomes in patients with nonalcoholic fatty liver disease. J Lipid Res. (2019) 60:176-85. doi: 10.1194/jlr.P089953

63. Stickel F, Lutz P, Buch S, Nischalke HD, Silva I, Rausch V, et al. Genetic variation in HSD17B13 reduces the risk of developing cirrhosis and hepatocellular carcinoma in alcohol misusers. Hepatology. (2019). doi: 10.1002/hep.30996

64. Yang J, Trepo E, Nahon P, Cao Q, Moreno C, Letouze E, et al. A 17beta-hydroxysteroid dehydrogenase 13 variant protects from hepatocellular carcinoma development in alcoholic liver disease. Hepatology. (2019) 70:231-40. doi: 10.1002/hep.30623

65. Romeo S, Kozlitina J, Xing C, Pertsemlidis A, Cox D, Pennacchio LA, et al. Genetic variation in PNPLA3 confers susceptibility to nonalcoholic fatty liver disease. Nat Genet. (2008) 40:1461-5. doi: 10.1038/ng.257

66. Romeo S, Sentinelli F, Cambuli VM, Incani M, Congiu T, Matta V, et al. The $148 \mathrm{M}$ allele of the PNPLA3 gene is associated with indices of liver damage early in life. J Hepatol. (2010) 53:335-8. doi: 10.1016/j.jhep.2010.02.034

67. Romeo S, Sentinelli F, Dash S, Yeo GS, Savage DB, Leonetti F, et al. Morbid obesity exposes the association between PNPLA3 I148M. (rs738409) and indices of hepatic injury in individuals of European descent. Int J Obes. (2010) 34:190-4. doi: 10.1038/ijo.2009.216

68. Rotman Y, Koh C, Zmuda JM, Kleiner DE, Liang TJ, Nash CRN. The association of genetic variability in patatin-like phospholipase domaincontaining protein 3. (PNPLA3) with histological severity of nonalcoholic fatty liver disease. Hepatology. (2010) 52:894-903. doi: 10.1002/hep.23759

69. Salameh H, Hanayneh MA, Masadeh M, Naseemuddin M, Matin T, Erwin A, et al. PNPLA3 as a genetic determinant of risk for and severity of nonalcoholic fatty liver disease spectrum. J Clin Transl Hepatol. (2016) 4:175-91. doi: 10.14309/00000434-201510001-02091

70. Salameh H, Raff E, Erwin A, Seth D, Nischalke HD, Falleti E, et al. PNPLA3 gene polymorphism is associated with predisposition to and severity of alcoholic liver disease. Am J Gastroenterol. (2015) 110:846-56. doi: 10.1038/ajg.2015.137

71. Santoro N, Kursawe R, D'Adamo E, Dykas DJ, Zhang CK, Bale AE, et al. A common variant in the patatin-like phospholipase 3 gene. (PNPLA3) is associated with fatty liver disease in obese children and adolescents. Hepatology. (2010) 52:1281-90. doi: 10.1002/hep.23832

72. Scheiner B, Mandorfer M, Schwabl P, Payer BA, Bucsics T, Bota S, et al. The impact of PNPLA3 rs738409 SNP on liver fibrosis progression, portal hypertension and hepatic steatosis in HIV/HCV coinfection. PLoS ONE. (2015) 10:e0143429. doi: 10.1371/journal.pone.0143429

73. Seko Y, Yamaguchi K, Mizuno N, Okuda K, Takemura M, Taketani H, et al. Combination of PNPLA3 and TLL1 polymorphism can predict advanced fibrosis in Japanese patients with nonalcoholic fatty liver disease. J Gastroenterol. (2018) 53:438-48. doi: 10.1007/s00535-017-1372-8

74. Shen J, Wong GL, Chan HL, Chan HY, Yeung DK, Chan RS, et al. PNPLA3 gene polymorphism accounts for fatty liver in community subjects without metabolic syndrome. Aliment Pharmacol Ther. (2014) 39:532-9. doi: 10.1111/apt.12609

75. Shen J, Wong GL, Chan HL, Chan RS, Chan HY, Chu WC, et al. PNPLA3 gene polymorphism and response to lifestyle modification in patients with nonalcoholic fatty liver disease. 
J Gastroenterol Hepatol. (2015) 30:139-46. doi: 10.1111/jgh. 12656

76. Shen JH, Li YL, Li D, Wang NN, Jing L, Huang YH. The rs738409. (I148M) variant of the PNPLA3 gene and cirrhosis: a meta-analysis. J Lipid Res. (2015) 56:167-75. doi: 10.1194/jlr.M048777

77. Singal AG, Manjunath H, Yopp AC, Beg MS, Marrero JA, Gopal P, et al. The effect of PNPLA3 on fibrosis progression and development of hepatocellular carcinoma: a meta-analysis. Am J Gastroenterol. (2014) 109:325-34. doi: 10.1038/ajg.2013.476

78. Song G, Xiao C, Wang K, Wang Y, Chen J, Yu Y, et al. Association of patatinlike phospholipase domain-containing protein 3 gene polymorphisms with susceptibility of nonalcoholic fatty liver disease in a Han Chinese population. Medicine. (2016) 95:e4569. doi: 10.1097/MD.0000000000004569

79. Sookoian S, Castano GO, Burgueno AL, Gianotti TF, Rosselli MS, Pirola CJ. A nonsynonymous gene variant in the adiponutrin gene is associated with nonalcoholic fatty liver disease severity. J Lipid Res. (2009) 50:2111-6. doi: 10.1194/jlr.P900013-JLR200

80. Sookoian S, Castano GO, Pirola CJ. PNPLA3 I148M variant is associated with metabolic stress-response phenotype in patients with nonalcoholic fatty liver disease. Hepatology. (2015) 61:1769. doi: 10.1002/hep. 27390

81. Sookoian S, Pirola CJ. Meta-analysis of the influence of I148M variant of patatin-like phospholipase domain containing 3 gene. (PNPLA3) on the susceptibility and histological severity of nonalcoholic fatty liver disease. Hepatology. (2011) 53:1883-94. doi: 10.1002/hep.24283

82. Speliotes EK, Butler JL, Palmer CD, Voight BF, Consortium G, Consortium MI, et al. PNPLA3 variants specifically confer increased risk for histologic nonalcoholic fatty liver disease but not metabolic disease. Hepatology. (2010) 52:904-12. doi: 10.1002/hep.23768

83. Speliotes EK, Yerges-Armstrong LM, Wu J, Hernaez R, Kim LJ, Palmer CD, et al. Genome-wide association analysis identifies variants associated with nonalcoholic fatty liver disease that have distinct effects on metabolic traits. PLoS Genet. (2011) 7:e1001324. doi: 10.1371/journal.pgen.1001324

84. Stickel F, Buch S, Lau K, Meyer zu Schwabedissen H, Berg T, Ridinger M, et al. Genetic variation in the PNPLA3 gene is associated with alcoholic liver injury in caucasians. Hepatology. (2011) 53:86-95. doi: 10.1002/hep. 24017

85. Stickel F, Buch S, Nischalke HD, Weiss KH, Gotthardt D, Fischer J, et al. Genetic variants in PNPLA3 and TM6SF2 predispose to the development of hepatocellular carcinoma in individuals with alcohol-related cirrhosis. Am J Gastroenterol. (2018) 113:1475-83. doi: 10.1038/s41395-018-0041-8

86. Tai CM, Huang CK, Tu HP, Hwang JC, Yeh ML, Huang CF, et al. Interactions of a PPARGC1A variant and a PNPLA3 variant affect nonalcoholic steatohepatitis in severely obese taiwanese patients. Medicine. (2016) 95:e3120. doi: 10.1097/MD.0000000000003120

87. Takeuchi Y, Ikeda F, Moritou Y, Hagihara H, Yasunaka T, Kuwaki K, et al. The impact of patatin-like phospholipase domain-containing protein 3 polymorphism on hepatocellular carcinoma prognosis. J Gastroenterol. (2013) 48:405-12. doi: 10.1007/s00535-012-0647-3

88. Tamaki N, Kurosaki M, Higuchi M, Takada H, Nakakuki N, Yasui Y, et al. Genetic polymorphisms of IL28B and PNPLA3 are predictive for HCV related rapid fibrosis progression and identify patients who require urgent antiviral treatment with new regimens. PLOS ONE. (2015) 10:e0137351. doi: 10.1371/journal.pone.0137351

89. Tian C, Stokowski RP, Kershenobich D, Ballinger DG, Hinds DA. Variant in PNPLA3 is associated with alcoholic liver disease. Nat Genet. (2010) 42:21-3. doi: $10.1038 /$ ng.488

90. Tong J, Guo J, Hu J, Hou S, Zhang Y, Li Q. Correlation between patatin-like phospholipase domain-containing protein 3 gene polymorphisms and liver cirrhosis in a chinese han population with chronic hepatitis B. Hepat Mon. (2014) 14:e18943. doi: 10.5812/hepatmon.18943

91. Trepo E, Gustot T, Degre D, Lemmers A, Verset L, Demetter P, et al. Common polymorphism in the PNPLA3/adiponutrin gene confers higher risk of cirrhosis and liver damage in alcoholic liver disease. J Hepatol. (2011) 55:906-12. doi: 10.1016/j.jhep.2011.01.028

92. Trepo E, Guyot E, Ganne-Carrie N, Degre D, Gustot T, Franchimont D, et al. PNPLA3. (rs738409 C>G) is a common risk variant associated with hepatocellular carcinoma in alcoholic cirrhosis. Hepatology. (2012) 55:13078. doi: 10.1002/hep. 25518

93. Trepo E, Nahon P, Bontempi G, Valenti L, Falleti E, Nischalke HD, et al. Association between the PNPLA3. (rs738409 $\mathrm{C}>\mathrm{G}$ ) variant and hepatocellular carcinoma: Evidence from a meta-analysis of individual participant data. Hepatology. (2014) 59:2170-7. doi: 10.1002/hep.26767

94. Trepo E, Pradat P, Potthoff A, Momozawa Y, Quertinmont E, Gustot T, et al. Impact of patatin-like phospholipase-3. (rs738409 C > G) polymorphism on fibrosis progression and steatosis in chronic hepatitis C. Hepatology. (2011) 54:60-9. doi: 10.1002/hep.24350

95. Ueyama M, Nishida N, Korenaga M, Korenaga K, Kumagai E, Yanai H, et al. The impact of PNPLA3 and JAZF1 on hepatocellular carcinoma in nonviral hepatitis patients with type 2 diabetes mellitus. J Gastroenterol. (2016) 51:370-9. doi: 10.1007/s00535-015-1116-6

96. Valenti L, Alisi A, Galmozzi E, Bartuli A, Del Menico B, Alterio A, et al. I148M patatin-like phospholipase domain-containing 3 gene variant and severity of pediatric nonalcoholic fatty liver disease. Hepatology. (2010) 52:1274-80. doi: 10.1002/hep.23823

97. Valenti L, Al-Serri A, Daly AK, Galmozzi E, Rametta R, Dongiovanni $\mathrm{P}$, et al. Homozygosity for the patatin-like phospholipase-3/adiponutrin I148M polymorphism influences liver fibrosis in patients with nonalcoholic fatty liver disease. Hepatology. (2010) 51:1209-17. doi: 10.1002/hep. 23622

98. Verrijken A, Beckers S, Francque S, Hilden H, Caron S, Zegers D, et al. A gene variant of PNPLA3, but not of APOC3, is associated with histological parameters of NAFLD in an obese population. Obesity. (2013) 21:2138-45. doi: 10.1002/oby.20366

99. Vespasiani-Gentilucci U, Gallo P, Porcari A, Carotti S, Galati G, Piccioni L, et al. The PNPLA3 rs738409 C > G polymorphism is associated with the risk of progression to cirrhosis in NAFLD patients. Scand J Gastroenterol. (2016) 51:967-73. doi: 10.3109/00365521.2016.1161066

100. Vigano M, Valenti L, Lampertico P, Facchetti F, Motta BM, D’Ambrosio R, et al. Patatin-like phospholipase domain-containing 3 I148M affects liver steatosis in patients with chronic hepatitis B. Hepatology. (2013) 58:1245-52. doi: 10.1002/hep.26445

101. Wang CW, Lin HY, Shin SJ, Yu ML, Lin ZY, Dai CY, et al. The PNPLA3 I148M polymorphism is associated with insulin resistance and nonalcoholic fatty liver disease in a normoglycaemic population. Liver Int. (2011) 31:132631. doi: 10.1111/j.1478-3231.2011.02526.x

102. Wang X, Liu Z, Wang K, Wang Z, Sun X, Zhong L, et al. Additive effects of the risk alleles of PNPLA3 and TM6SF2 on non-alcoholic fatty liver disease. (NAFLD) in a Chinese population. Front Genet. (2016) 7:140. doi: 10.3389/fgene.2016.00140

103. Xia MF, Ling Y, Bian H, Lin HD, Yan HM, Chang XX, et al. I148M variant of PNPLA3 increases the susceptibility to non-alcoholic fatty liver disease caused by obesity and metabolic disorders. Aliment Pharmacol Ther. (2016) 43:631-42. doi: 10.1111/apt.13521

104. Xu M, Li Y, Zhang S, Wang X, Shen J, Zhang S. Interaction of TM6SF2 E167K and PNPLA3 I148M variants in NAFLD in northeast China. Ann Hepatol. (2019) 18:456-60. doi: 10.1016/j.aohep.2018.10.005

105. Xu R, Tao A, Zhang S, Deng Y, Chen G. Association between patatin-like phospholipase domain containing 3 gene. (PNPLA3) polymorphisms and nonalcoholic fatty liver disease: a HuGE review and meta-analysis. Sci Rep. (2015) 5:9284. doi: 10.1038/srep09284

106. Yang J, Trepo E, Nahon P, Cao Q, Moreno C, Letouze E, et al. PNPLA3 and TM6SF2 variants as risk factors of hepatocellular carcinoma across various etiologies and severity of underlying liver diseases. Int J Cancer. (2019) 144:533-44. doi: 10.1002/ijc.31910

107. Yasui K, Kawaguchi T, Shima T, Mitsuyoshi H, Seki K, Sendo R, et al. Effect of PNPLA3 rs738409 variant. (I148 M) on hepatic steatosis, necroinflammation, and fibrosis in Japanese patients with chronic hepatitis C. J Gastroenterol. (2015) 50:887-93. doi: 10.1007/s00535-014-1018-Z

108. Yen YH, Tsai MC, Wu CK, Chang KC, Hung CH, Chiu KW, et al. Association between PNPLA3. (rs738409 C>G) variant and hepatocellular carcinoma in Asian chronic hepatitis C patients: a longitudinal study. J Formos Med Assoc. (2018) 117:833-40. doi: 10.1016/j.jfma.2017. 10.003

109. Young KA, Palmer ND, Fingerlin TE, Langefeld CD, Norris JM, Wang $\mathrm{N}$, et al. Genome-wide association study identifies loci for liver enzyme concentrations in mexican americans: the GUARDIAN consortium. Obesity. (2019) 27:1331-37. doi: 10.1002/oby. 22527

110. Yuan X, Waterworth D, Perry JR, Lim N, Song K, Chambers JC, et al. Population-based genome-wide association studies reveal six loci influencing 
plasma levels of liver enzymes. Am J Hum Genet. (2008) 83:520-8. doi: 10.1016/j.ajhg.2008.09.012

111. Zain SM, Mohamed R, Mahadeva S, Cheah PL, Rampal S, Basu RC, et al. A multi-ethnic study of a PNPLA3 gene variant and its association with disease severity in non-alcoholic fatty liver disease. Hum Genet. (2012) 131:1145-52. doi: 10.1007/s00439-012-1141-y

112. Zampino R, Coppola N, Cirillo G, Boemio A, Grandone A, Stanzione $\mathrm{M}$, et al. Patatin-like phospholipase domain-containing $3 \mathrm{I} 148 \mathrm{M}$ variant is associated with liver steatosis and fat distribution in chronic hepatitis B. Dig Dis Sci. (2015) 60:3005-10. doi: 10.1007/s10620-015-3716-7

113. Zhang S, Wu H, Wu X, Lian W, Wang Y, Zhang X, et al. Association between PNPLA3 rs738409 polymorphisms and risk of hepatocellular carcinoma and its development in patients with cirrhosis: a meta-analysis. Int J Clin Exp Med. (2015) 8:6638-49.

114. Zhang Y, Cai W, Song J, Miao L, Zhang B, Xu Q, et al. Association between the PNPLA3 I148M polymorphism and non-alcoholic fatty liver disease in the Uygur and Han ethnic groups of northwestern China. PLoS ONE. (2014) 9:e108381. doi: 10.1371/journal.pone.0108381

115. Zhang Y, Guo T, Yang F, Mao Y, Li L, Liu C, et al. Single-nucleotide rs738409 polymorphisms in the PNPLA3 gene are strongly associated with alcoholic liver disease in Han Chinese males. Hepatol Int. (2018) 12:429-37. doi: 10.1007/s12072-018-9889-3

116. Liangpunsakul S, Beaudoin JJ, Shah VH, Puri P, Sanyal AJ, Kamath PS, et al. Interaction between the patatin-like phospholipase domain-containing protein 3 genotype and coffee drinking and the risk for acute alcoholic hepatitis. Hepatol Commun. (2018) 2:29-34. doi: 10.1002/hep4.1123

117. Shang L, Mashek DG. The underpinnings of PNPLA3-mediated fatty liver emerge. Hepatology. (2019). doi: 10.1002/hep.30888. [Epub ahead of print].

118. Baulande S, Lasnier F, Lucas M, Pairault J. Adiponutrin, a transmembrane protein corresponding to a novel dietary- and obesity-linked mRNA specifically expressed in the adipose lineage. J Biol Chem. (2001) 276:3333644. doi: 10.1074/jbc.M105193200

119. Jenkins CM, Mancuso DJ, Yan W, Sims HF, Gibson B, Gross RW. Identification, cloning, expression, and purification of three novel human calcium-independent phospholipase A2 family members possessing triacylglycerol lipase and acylglycerol transacylase activities. J Biol Chem. (2004) 279:48968-75. doi: 10.1074/jbc.M407841200

120. Wilson PA, Gardner SD, Lambie NM, Commans SA, Crowther DJ. Characterization of the human patatin-like phospholipase family. J Lipid Res. (2006) 47:1940-9. doi: 10.1194/jlr.M600185-JLR200

121. Huang Y, He S, Li JZ, Seo YK, Osborne TF, Cohen JC, et al. A feed-forward loop amplifies nutritional regulation of PNPLA3. Proc Natl Acad Sci USA. (2010) 107:7892-7. doi: 10.1073/pnas.1003585107

122. Lake AC, Sun Y, Li JL, Kim JE, Johnson JW, Li D, et al. Expression, regulation, and triglyceride hydrolase activity of Adiponutrin family members. J Lipid Res. (2005) 46:2477-87. doi: 10.1194/jlr.M500290-JLR200

123. Dubuquoy C, Robichon C, Lasnier F, Langlois C, Dugail I, Foufelle $\mathrm{F}$, et al. Distinct regulation of adiponutrin/PNPLA3 gene expression by the transcription factors ChREBP and SREBP1c in mouse and human hepatocytes. J Hepatol. (2011) 55:145-53. doi: 10.1016/j.jhep.2010.10.024

124. Liang H, Xu J, Xu F, Liu H, Yuan D, Yuan S, Cai M, et al. The SRE motif in the human PNPLA3 promoter. (-97 to-88 bp) mediates transactivational effects of SREBP-1c. J Cell Physiol. (2015) 230:2224-32. doi: 10.1002/jcp.24951

125. Perttila J, Huaman-Samanez C, Caron S, Tanhuanpaa K, Staels B, YkiJarvinen $\mathrm{H}$, et al. PNPLA3 is regulated by glucose in human hepatocytes, and its I148M mutant slows down triglyceride hydrolysis. Am J Physiol Endocrinol Metab. (2012) 302:E1063-9. doi: 10.1152/ajpendo.00125.2011

126. Basantani MK, Sitnick MT, Cai L, Brenner DS, Gardner NP, Li JZ, et al. Pnpla3/Adiponutrin deficiency in mice does not contribute to fatty liver disease or metabolic syndrome. J Lipid Res. (2011) 52:318-29. doi: 10.1194/jlr.M011205

127. Chen W, Chang B, Li L, Chan L. Patatin-like phospholipase domaincontaining 3/adiponutrin deficiency in mice is not associated with fatty liver disease. Hepatology. (2010) 52:1134-42. doi: 10.1002/hep.23812

128. Li JZ, Huang Y, Karaman R, Ivanova PT, Brown HA, Roddy T, et al. Chronic overexpression of PNPLA3I148M in mouse liver causes hepatic steatosis. $J$ Clin Invest. (2012) 122:4130-44. doi: 10.1172/JCI65179
129. BasuRay S, Smagris E, Cohen JC, Hobbs HH. The PNPLA3 variant associated with fatty liver disease. (I148M) accumulates on lipid droplets by evading ubiquitylation. Hepatology. (2017) 66:1111-24. doi: 10.1002/hep.29273

130. Smagris E, BasuRay S, Li J, Huang Y, Lai KM, Gromada J, et al. Pnpla3I148M knockin mice accumulate PNPLA3 on lipid droplets and develop hepatic steatosis. Hepatology. (2015) 61:108-18. doi: 10.1002/hep.27242

131. Linden D, Ahnmark A, Pingitore P, Ciociola E, Ahlstedt I, Andreasson AC, et al. Pnpla3 silencing with antisense oligonucleotides ameliorates nonalcoholic steatohepatitis and fibrosis in Pnpla3 I148M knock-in mice. Mol Metab. (2019) 22:49-61. doi: 10.1016/j.molmet.2019.01.013

132. Huang Y, Cohen JC, Hobbs HH. Expression and characterization of a PNPLA3 protein isoform. (I148M) associated with nonalcoholic fatty liver disease. J Biol Chem. (2011) 286:37085-93. doi: 10.1074/jbc.M111.290114

133. He S, McPhaul C, Li JZ, Garuti R, Kinch L, Grishin NV, et al. A sequence variation. (I148M) in PNPLA3 associated with nonalcoholic fatty liver disease disrupts triglyceride hydrolysis. J Biol Chem. (2010) 285:6706-15. doi: 10.1074/jbc.M109.064501

134. Pingitore P, Pirazzi C, Mancina RM, Motta BM, Indiveri C, Pujia A, et al. Recombinant PNPLA3 protein shows triglyceride hydrolase activity and its I148M mutation results in loss of function. Biochim Biophys Acta. (2014) 1841:574-80. doi: 10.1016/j.bbalip.2013.12.006

135. Pirazzi C, Valenti L, Motta BM, Pingitore P, Hedfalk K, Mancina RM, et al. PNPLA3 has retinyl-palmitate lipase activity in human hepatic stellate cells. Hum Mol Genet. (2014) 23:4077-85. doi: 10.1093/hmg/ddu121

136. Hellemans K, Grinko I, Rombouts K, Schuppan D, Geerts A. All-trans and 9-cis retinoic acid alter rat hepatic stellate cell phenotype differentially. Gut. (1999) 45:134-42. doi: 10.1136/gut.45.1.134

137. Hellemans K, Verbuyst P, Quartier E, Schuit F, Rombouts K, Chandraratna RA, et al. Differential modulation of rat hepatic stellate phenotype by natural and synthetic retinoids. Hepatology. (2004) 39:97-108. doi: $10.1002 /$ hep. 20015

138. Wang L, Tankersley LR, Tang M, Potter JJ, Mezey E. Regulation of alpha 2(I) collagen expression in stellate cells by retinoic acid and retinoid X receptors through interactions with their cofactors. Arch Biochem Biophys. (2004) 428:92-8. doi: 10.1016/j.abb.2004.05.004

139. Bruschi FV, Claudel T, Tardelli M, Caligiuri A, Stulnig TM, Marra F, et al. The PNPLA3 I148M variant modulates the fibrogenic phenotype of human hepatic stellate cells. Hepatology. (2017) 65:1875-90. doi: 10.1002/hep.29041

140. Wang Y, Kory N, BasuRay S, Cohen JC, Hobbs HH. PNPLA3, CGI-58, and inhibition of hepatic triglyceride hydrolysis in mice. Hepatology. (2019) 69:2427-41. doi: 10.1002/hep.30583

141. Murugesan S, Goldberg EB, Dou E, Brown WJ. Identification of diverse lipid droplet targeting motifs in the PNPLA family of triglyceride lipases. PLoS ONE. (2013) 8:e64950. doi: 10.1371/journal.pone.0064950

142. Chamoun Z, Vacca F, Parton RG, Gruenberg J. PNPLA3/adiponutrin functions in lipid droplet formation. Biol Cell. (2013) 105:219-33. doi: $10.1111 /$ boc. 201200036

143. BasuRay S, Wang Y, Smagris E, Cohen JC, Hobbs HH. Accumulation of PNPLA3 on lipid droplets is the basis of associated hepatic steatosis. Proc Natl Acad Sci USA. (2019) 116:9521-6. doi: 10.1073/pnas.1901974116

144. Negoita F, Blomdahl J, Wasserstrom S, Winberg ME, Osmark P, Larsson S, et al. PNPLA3 variant M148 causes resistance to starvation-mediated lipid droplet autophagy in human hepatocytes. J Cell Biochem. (2019) 120:343-56. doi: $10.1002 / j \mathrm{cb} .27378$

145. Yang A, Mottillo EP, Mladenovic-Lucas L, Zhou L, Granneman JG. Dynamic interactions of ABHD5 with PNPLA3 regulate triacylglycerol metabolism in brown adipocytes. Nat Metab. (2019) 1:560-9. doi: 10.1038/s42255-019-0066-3

146. Pingitore P, Dongiovanni P, Motta BM, Meroni M, Lepore SM, Mancina RM, et al. PNPLA3 overexpression results in reduction of proteins predisposing to fibrosis. Hum Mol Genet. (2016) 25:5212-22. doi: 10.1093/hmg/ddw341

147. Bruschi FV, Claudel T, Tardelli M, Starlinger P, Marra F, Trauner M. PNPLA3 I148M Variant impairs liver $\mathrm{X}$ receptor signaling and cholesterol homeostasis in human hepatic stellate cells. Hepatol Commun. (2019) 3:1191-204. doi: 10.1002/hep4.1395

148. Kollerits B, Coassin S, Beckmann ND, Teumer A, Kiechl S, Doring A, et al. Genetic evidence for a role of adiponutrin in the metabolism of 
apolipoprotein B-containing lipoproteins. Hum Mol Genet. (2009) 18:466976. doi: $10.1093 / \mathrm{hmg} / \mathrm{ddp} 424$

149. Hotta K, Yoneda M, Hyogo H, Ochi H, Mizusawa S, Ueno T, et al. Association of the rs738409 polymorphism in PNPLA3 with liver damage and the development of nonalcoholic fatty liver disease. BMC Med Genet. (2010) 11:172. doi: 10.1186/1471-2350-11-172

150. Krawczyk M, Grunhage F, Zimmer V, Lammert F. Variant adiponutrin. (PNPLA3) represents a common fibrosis risk gene: non-invasive elastography-based study in chronic liver disease. J Hepatol. (2011) 55:299-306. doi: 10.1016/j.jhep.2010.10.042

151. Kitamoto T, Kitamoto A, Yoneda M, Hyogo H, Ochi H, Nakamura T, et al. Genome-wide scan revealed that polymorphisms in the PNPLA3, SAMM50, and PARVB genes are associated with development and progression of nonalcoholic fatty liver disease in Japan. Hum Genet. (2013) 132:783-92. doi: 10.1007/s00439-013-1294-3

152. Hernaez R, McLean J, Lazo M, Brancati FL, Hirschhorn JN, Borecki IB, et al. Association between variants in or near PNPLA3, GCKR, and PPP1R3B with ultrasound-defined steatosis based on data from the third National Health and Nutrition Examination Survey. Clin Gastroenterol Hepatol. (2013) 11:1183-90.e1182. doi: 10.1016/j.cgh.2013.02.011

153. Hassan MM, Kaseb A, Etzel CJ, El-Serag H, Spitz MR, Chang P, et al. Genetic variation in the PNPLA3 gene and hepatocellular carcinoma in USA: risk and prognosis prediction. Mol Carcinog. (2013) 52(Suppl 1):E139-47. doi: 10.1002/mc.22057

154. Kupcinskas J, Valantiene I, Varkalaite G, Steponaitiene R, Skieceviciene J, Sumskiene J, et al. PNPLA3 and RNF7 gene variants are associated with the risk of developing liver fibrosis and cirrhosis in an eastern european population. J Gastrointestin Liver Dis. (2017) 26:37-43. doi: 10.15403/jgld.2014.1121.261.pnp

155. Beaudoin JJ, Long N, Liangpunsakul S, Puri P, Kamath PS, Shah $\mathrm{V}$, et al. An exploratory genome-wide analysis of genetic risk for alcoholic hepatitis. Scand J Gastroenterol. (2017) 52:1263-9. doi: 10.1080/00365521.2017.1359664

156. Chung GE, Lee Y, Yim JY, Choe EK, Kwak MS, Yang JI, et al. Genetic polymorphisms of PNPLA3 and SAMM50 are associated with nonalcoholic fatty liver disease in a korean population. Gut Liver. (2018) 12:316-23. doi: $10.5009 /$ gnl17306

157. Namjou B, Lingren T, Huang Y, Parameswaran S, Cobb BL, Stanaway IB, et al. GWAS and enrichment analyses of non-alcoholic fatty liver disease identify new trait-associated genes and pathways across eMERGE Network. BMC Med. (2019) 17:135. doi: 10.1186/s12916-019-1364-z

158. Burza MA, Molinaro A, Attilia ML, Rotondo C, Attilia F, Ceccanti M, et al. PNPLA3 I148M. (rs738409) genetic variant and age at onset of at-risk alcohol consumption are independent risk factors for alcoholic cirrhosis. Liver Int. (2014) 34:514-20. doi: 10.1111/liv.12310

159. Chamorro AJ, Torres JL, Miron-Canelo JA, Gonzalez-Sarmiento R, Laso FJ, Marcos M. Systematic review with meta-analysis: the I148M variant of patatin-like phospholipase domain-containing 3 gene. (PNPLA3) is significantly associated with alcoholic liver cirrhosis. Aliment Pharmacol Ther. (2014) 40:571-81. doi: 10.1111/apt.12890

160. Falleti E, Fabris C, Cmet S, Cussigh A, Bitetto D, Fontanini E, et al. PNPLA3 rs738409C/G polymorphism in cirrhosis: relationship with the aetiology of liver disease and hepatocellular carcinoma occurrence. Liver Int. (2011) 31:1137-43. doi: 10.1111/j.1478-3231.2011.02534.x
161. Burza MA, Pirazzi C, Maglio C, Sjoholm K, Mancina RM, Svensson PA, et al. PNPLA3 I148M. (rs738409) genetic variant is associated with hepatocellular carcinoma in obese individuals. Dig Liver Dis. (2012) 44:103741. doi: 10.1016/j.dld.2012.05.006

162. Falleti E, Cussigh A, Cmet S, Fabris C, Toniutto P. PNPLA3 rs738409 and TM6SF2 rs58542926 variants increase the risk of hepatocellular carcinoma in alcoholic cirrhosis. Dig Liver Dis. (2016) 48:69-75. doi: 10.1016/j.dld.2015.09.009

163. Gao X, Liu W, Yang L, Zhang X, Ma N, Wang L, et al. Association between PNPLA3 gene polymorphisms and risk of hepatitis B virus-related hepatocellular carcinoma in Han population in China:a case-control study. Scand J Gastroenterol. (2017) 52:1120-7. doi: 10.1080/00365521.2017.1334088

164. Guyot E, Sutton A, Rufat P, Laguillier C, Mansouri A, Moreau R, et al. PNPLA3 rs738409, hepatocellular carcinoma occurrence and risk model prediction in patients with cirrhosis. J Hepatol. (2013) 58:312-8. doi: 10.1016/j.jhep.2012.09.036

165. Huang Z, Guo X, Zhang G, Liang L, Nong B. Correlation between PNPLA3 rs738409 polymorphism and hepatocellular carcinoma: a metaanalysis of 10,330 subjects. Int J Biol Markers. (2019) 34:117-22. doi: $10.1177 / 1724600818812471$

166. Li JF, Zheng EQ, Xie M. Association between rs738409 polymorphism in patatin-like phospholipase domain-containing protein 3. (PNPLA3) gene and hepatocellular carcinoma susceptibility: evidence from case-control studies. Gene. (2019) 685:143-8. doi: 10.1016/j.gene.2018.11.012

167. Liu YL, Patman GL, Leathart JB, Piguet AC, Burt AD, Dufour JF, et al. Carriage of the PNPLA3 rs738409 C $>$ G polymorphism confers an increased risk of non-alcoholic fatty liver disease associated hepatocellular carcinoma. J Hepatol. (2014) 61:75-81. doi: 10.1016/j.jhep.2014.02.030

168. Nischalke HD, Berger C, Luda C, Berg T, Muller T, Grunhage F, et al. The PNPLA3 rs738409 148M/M genotype is a risk factor for liver cancer in alcoholic cirrhosis but shows no or weak association in hepatitis $\mathrm{C}$ cirrhosis. PLoS ONE. (2011) 6:e27087. doi: 10.1371/journal.pone.0027087

169. Raksayot M, Chuaypen N, Khlaiphuengsin A, Pinjaroen N, Treeprasertsuk S, Poovorawan Y, et al. Independent and additive effects of PNPLA3 and TM6SF2 polymorphisms on the development of non-B, nonC hepatocellular carcinoma. J Gastroenterol. (2019) 54:427-36. doi: $10.1007 /$ s00535-018-01533-x

170. Sookoian S, Pirola CJ. PNPLA3, the triacylglycerol synthesis/hydrolysis/storage dilemma, and nonalcoholic fatty liver disease. World J Gastroenterol. (2012) 18:6018-26. doi: 10.3748/wjg.v18.i42.6018

171. Mullard A. PCSK9-lowering RNAi contender clears first phase III trial. Nat Rev Drug Discov. (2019) 18:737. doi: 10.1038/d41573-019-00153-1

Conflict of Interest: The author declares that the research was conducted in the absence of any commercial or financial relationships that could be construed as a potential conflict of interest.

Copyright $\odot 2019$ Dong. This is an open-access article distributed under the terms of the Creative Commons Attribution License (CC BY). The use, distribution or reproduction in other forums is permitted, provided the original author(s) and the copyright owner(s) are credited and that the original publication in this journal is cited, in accordance with accepted academic practice. No use, distribution or reproduction is permitted which does not comply with these terms. 